\begin{tabular}{|c|c|c|}
\hline \multirow{3}{*}{ IDUNAS } & NATURAL \& APPLIED SCIENCES & 2020 \\
& Jol. 3 \\
No.1 \\
$(47-58)$
\end{tabular}

\title{
Bacteriological Assessment of Selected Hand-Pumped Boreholes Water Sources in Malete Environs, Kwara State Nigeria.
}

\author{
Research Article \\ Awe Sunday $^{*}$ (iD), Faloye Oyinade ${ }^{2}$ \\ l Department of Biosciences and Biotechnology, Kwara State University, Malate, Ilorin Nigeria \\ 2 Department of Microbiology, University of Ilorin, Nigeria \\ Correspondence to: A. Sunday, Department of Biosciences and Biotechnology, Kwara State University, Malate, Ilorin Nigeria
}

Author E-mails

asflor6@gmail.com

sunday.awe@kwasu.edu.ng DOI: 10.38061/idunas.731180

Received: May 3, 2020; Accepted: June 23, 2020

\section{Abstract}

A significant source of water for domestic use in Nigeria and developing countries is groundwater. Groundwater is generally very clean but pollution can result, as nutrients and toxic chemicals find their way into it. This study assessed the microbial quality of water (hand-pumped boreholes) at six areas in Malete environs. Water samples were collected in triplicates and subjected to physicochemical (temperature, $\mathrm{pH}$, conductivity, turbidity, salinity and hardness), microbiological (heterotrophic and coliform counts) and molecular analysis using standard methods. The temperature generally ranged from $26.45 \pm 0.20$ to $29.3 \pm 0.19^{\circ} \mathrm{C}, \mathrm{pH}$ ranged between $7.6 \pm 0.00$ and $8.2 \pm 0.012$. Turbidity was generally $<5 \mathrm{NTU}$, conductivity was $<250 \mu \mathrm{S} / \mathrm{cm}$ and hardness was $<150 \mathrm{mg} / \mathrm{L}$. The values were within acceptable range stated by World Health Organization (WHO) and the National Standard for Drinking Water Quality (NSDWQ). Escherichia coli, Stapylococus aureus, Streptococcus pneumoniae and Klebsiella oxytoca were found in some water samples. Faecal coliform was found in $83.3 \%$ of the hand-pumped boreholes, these high prevalence of contaminated water is attributable to the largely contaminated environments around some of the wells which was littered with various forms of refuse. Public awareness on the dangers associated with the construction of hand-pumped boreholes at a distance less than 15 meters away from the septic tank should be increased. Also hand-pumped boreholes water samples that do not meet the standard should be treated before consumption.

Keywords: Hand-pumped boreholes, faecal contamination, portability, anthropogenic activities

\section{INTRODUCTION}

Lack of potable water is a problem, which affects billions of people worldwide. About 1.1 billion people do not have access to any form of source of potable water and about 1.6 million deaths result annually as a direct consequence of lack of access to potable water and basic sanitation (WHO, 2016). Although water occupies a large portion $(70 \%)$ of the earth's surface, availability of improved water source for 
domestic use especially in Nigeria and other developing countries in the world is still very low. Potable water is one of the most considered necessities of all urban and rural amenities and is requisite for man's activities. Both natural influences and human activities are factors responsible for the quality of any body of surface or ground water (Kolawole et al., 2013). Regional government established Water Boards Corporation to provide safe water for the communal folks. Federal Government of Nigeria resulted in the establishment of some federal agencies which include River Basin Development Authorities, the Federal Ministry of Water Resources (1976) and National Water Resources Institute (1977) in early seventies as a result of drought to formulate policies, manpower training, research and give advice on domestic water supply to the communities.

However, just before the commencement of this programme, only $22 \%$ of the rural and $55 \%$ of the urban population could use portable water. The situation has increased only marginally. The delivery of water supply systems, especially to the Rural Areas in Nigeria, has generally been inadequate in relation to desired goals and objectives.

Only $50 \%$ of the urban population and about $39 \%$ of rural communities have access to portable water. To solve problems of water shortage in the rural communities, World Bank and other related organizations postulated that hand pump well water should be provided to combat this shortage.

Sewage or human and animal waste are the major sources of danger accompanying with drinking water sources (Hague, 2019). Locating drinking water system (wells and boreholes) close to a refuse dumpsite or landfill is another problem. Therefore, regular and frequent examination of water is essential as contamination may be intermittent and may not be detected by simple tests.

Due to lack of awareness in Nigeria, groundwater contamination is one of the least recognized environmental problems since contamination are not as noticeable as those affecting surface water (Adeyemi et al., 2007).

Over the last eras access to safe potable water has improved in Nigeria and almost every part of the world, around 1.1 billion people are still facing water shortage and over 2.6 billion worldwide lack access to adequate hygiene resulting in water borne sicknesses such as cholera, diarrheal disease, botulism, E. coli infection, dysentery, legionellosis, leptospirosis, salmonellosis, typhoid fever and vibrio illness (Adogo et al., 2016).

Most borehole locations are very close to sanitary pipelines, which transverse the septic tank absorption fields. The sewer and the cast pipes for the transportation of water are subjected to leakages, and sometimes experience accidental backflow or back seepage of polluted water. This may occur from toilets and wash bowls, resulting in the contamination of water supply pipes through leakages. Thus, fecal coliform bacteria might be introduced into the well.

E. coli presence in water suggests presence of enteric fecal pollution (Ivey et al., 2006), this organism is the major causative agent of diarrhoea, urinary tract infection, hemorrhagic colitis and haemolyticuraemia syndrome.

This study therefore, was designed to assess the qualities of water samples from hand pump well, in addition taking into consideration the EPA'S recommendation for acceptable distance between a water well and a septic tank in different communities in Malete environs, Kwara State Nigeria. 


\section{MATERIALS AND METHODS}

\section{Study Area}

This study was conducted in Moro Local Government Area (LGA) of Kwara State. The LGA has an area of 3,272 $\mathrm{km}^{2}$ and an estimated population of 146,310 (Thomas, 2017). The LGA is made up of a conglomerate of agrarian villages. The physical environment of the primary sources of water in the villages, which were hand-pumped well were assessed. The sampling sites are (A: Akorede, B: Ashomu, C: Government secondary school Malate, D: Safari Village hostel, E: Isalebaale and F: Okete).

\section{Sample Collection}

Water samples were aseptically collected to prevent cross contamination in triplicates to presterilized $250 \mathrm{~mL}$ bottles from six different communities in Moro LGA. The sampling was done in August, 2019 which corresponds to the rainy season. The anthropogenic activity around the hand-pumped boreholes at each location were recorded (Aneja, 2003).

\section{Sampling Analysis}

Standard methods were used in carrying out the physicochemical and bacteriological analysis of the water samples.

\section{Determination of Physiochemical Parameters Determination of Temperature}

Mercury bulb thermometer calibrated in ${ }^{0} \mathrm{C}$ was used to measure temperature of each sample collected on site while electrical conductivity was measured with a CDM 83 conductivity meter (Radio Meter A/S Copenhagen, Denmark).

\section{Determination of $\mathbf{p H}$ and Other Parameters}

The $\mathrm{pH}$ of the water samples was measured using the electrometric method with a $\mathrm{pH}$ meter (model: HP $2211 \mathrm{ph} / \mathrm{ORP}$ meter) on site while other parameters such as total dissolved solids (TDS), total suspended solid (TSS), total solid (TS), total alkalinity and bicarbonate were determined colorimetricaly by Spectronic 20 (Gallenkamp,UK) (APHA, 1981).

\section{Bacteriological Analysis Enumeration of Total Heterotrophic Bacteria Counts (THC)}

Total viable count was done using the standard plate count method for the examination of water and waste water. Tenfold serial dilutions of $10^{-1}, 10^{-2}, 10^{-3}, 1 \mathrm{~mL}$ of the $10^{-2}$ and $10^{-3}$ dilutions were used to seed the properly labelled plates. The sterile molten nutrient agar cooled to about $45^{\circ} \mathrm{C}$ was poured into the appropriate plates and swirled to ensure proper mixing of the inoculum with the medium. The plates were then allowed to set and incubated at $37^{\circ} \mathrm{C}$ for $24 \mathrm{hrs}$. The plates were observed for growth after $24 \mathrm{hrs}$ and the numbers of discrete colonies on plates were observed and recorded in cfu/mL (Fawole and Oso, 2004).

\section{Enumeration of Total Thermotolerant (faecal) Coliform Counts}

This method of multiple tube test technique used for total coliform was also used to enumerate total thermotolerant coliforms. The only difference is that the temperature was increased from $37^{\circ} \mathrm{C}$ to $44^{\circ} \mathrm{C}$ for 24 to 48 hours. The high temperature at which the organisms grow is a characteristic of their uniqueness as indicator organism of faecal pollution of water (Fawole and Oso, 2004).

\section{Isolation of Pure Cultures}


Pure cultures were obtained by transferring different and distinct colonies into sterile solid nutrient agar plates using sterile inoculating loop and then streaked. The plates were then incubated and sub-cultured until satisfactorily pure cultures were obtained. The pure cultures obtained were then inoculated further onto agar slants in McCartney bottles, incubated at $37^{\circ} \mathrm{C}$ and stored in the refrigerator at $4^{\circ} \mathrm{C}$. The stock cultures were to serve as a source of reference whenever tests would be carried out on the isolates.

\section{Characterization and Identification of Bacterial Isolates}

The characterization and identification of bacterial isolates were based on the colonial morphology and biochemical characteristics. The colonial morphology of the microorganisms were based on the shapes, size, optical character, consistency, elevation and pigmentation, while the cellular morphology was determined through microscopic examination and staining techniques. After characterization, tentative identification was done using Bergey's Manual of Determinative Bacteriology (Cheesbrough, 2006).

\section{Molecular Characterization of Bacterial Isolates from Water Samples}

16SrDNA sequences processing Genomic DNA of the isolate was extracted following standard method. PCR amplification was carried out as follows: A pair of universal primer of 27F (5AGAGTTTGATCCTGGCTCAG-3) and 1492R (5- GGTTACCTTGTTACGACTT-3) was added to 2.5 $\mu 1$ PCR buffer containing $2 \mu 1 \mathrm{dNTP}$ mix, $0.2 \mu 1$ Taq DNA polymerase, $5 \mu 13$ of DNA template and $12.8 \mu 1$ sterile distilled water made up $25 \mu \mathrm{L}$ reaction volumes. The thermo-cycler PCR conditions were as follows: denaturation $(92 \circ \mathrm{C} / 1 \mathrm{~min})$, annealing $(54 \circ \mathrm{C} / 1 \mathrm{~min})$ and extension $(72 \circ \mathrm{C} / 1 \mathrm{~min})$ in 30 cycles (Miller et al., 2013). PCR product was loaded into well and electrophoresed on agarose gel at 120V for 45 minutes using a maxi gel system. The band on the gels was visualized by ultraviolet trans-illumination (Uvitec, Cambridge, UK), then sequenced. The 16S rRNA sequences of the isolate and similar sequences downloaded from NCBI database using the BLAST search program were aligned using the multiple sequence alignment generated using MEGA 6.0.

\section{Statistical Analysis}

Results of the Statistical analysis were expressed as mean and Standard deviation of triplicates and were statistically analyzed using ANOVA of SPSS statistical package of version 16.0. Values were considered significant at $\mathrm{p}<0.05$

\section{RESULTS}

\section{Anthropogenic Activities and State of Surrounding of the Wells}

Plate 1 shows the sampling sites as well as anthropogenic activities around the boreholes that were sampled, while Table 1 shows the sanitary surveillance of the surroundings of the boreholes that were sampled.

The descriptions of the sampling sites are shown in Table 1. About 33.3\% of the hand pump well are located close to the refuse sites while only $16.7 \%$ located close to septic tanks. The $\mathrm{pH}$ values ranged from 7.6 to 8.2 , the temperature ranged between $26.45 \pm 0.20^{\circ} \mathrm{C}$ to $29.3 \pm 0.19^{\circ} \mathrm{C}$, turbidity $(0.97$ to $2.30 \mathrm{NTU})$, dissolved oxygen $(5.35$ to $6.20 \mathrm{mg} / \mathrm{L})$, salinity $(0.017$ to $0.060 \mathrm{mg} / \mathrm{L})$, conductivity $(64.4$ to $97.4 \mu \mathrm{S} / \mathrm{cm})$ while the total hardness ranged between 3.27 and $5.00 \mathrm{ppm}$ (Table 2). The highest mean heterotrophic count was $2.93 \times 10^{4} \pm 6.67 \mathrm{cfu} / \mathrm{mL}$ for site $\mathrm{D}$ and the least was $1.06 \times 10^{2} \pm 3.33 \mathrm{cfu} / \mathrm{mL}$ for site $\mathrm{A}, 75.0 \pm 0.63 \mathrm{cfu} / \mathrm{mL}$ was the highest mean coliform count for site $\mathrm{D}$ and the least was $5.0 \pm 0.24 \mathrm{cfu} / \mathrm{mL}$ for site $\mathrm{B}$, while the highest total faecal coliform count was $65 \pm 0.18 \mathrm{cfu} / \mathrm{mL}$ with no faecal coliform in site B (Table 3 ). The Agarose gel Electrophoresis of the amplified DNA of the four bacterial isolates is shown in Figure 1. 


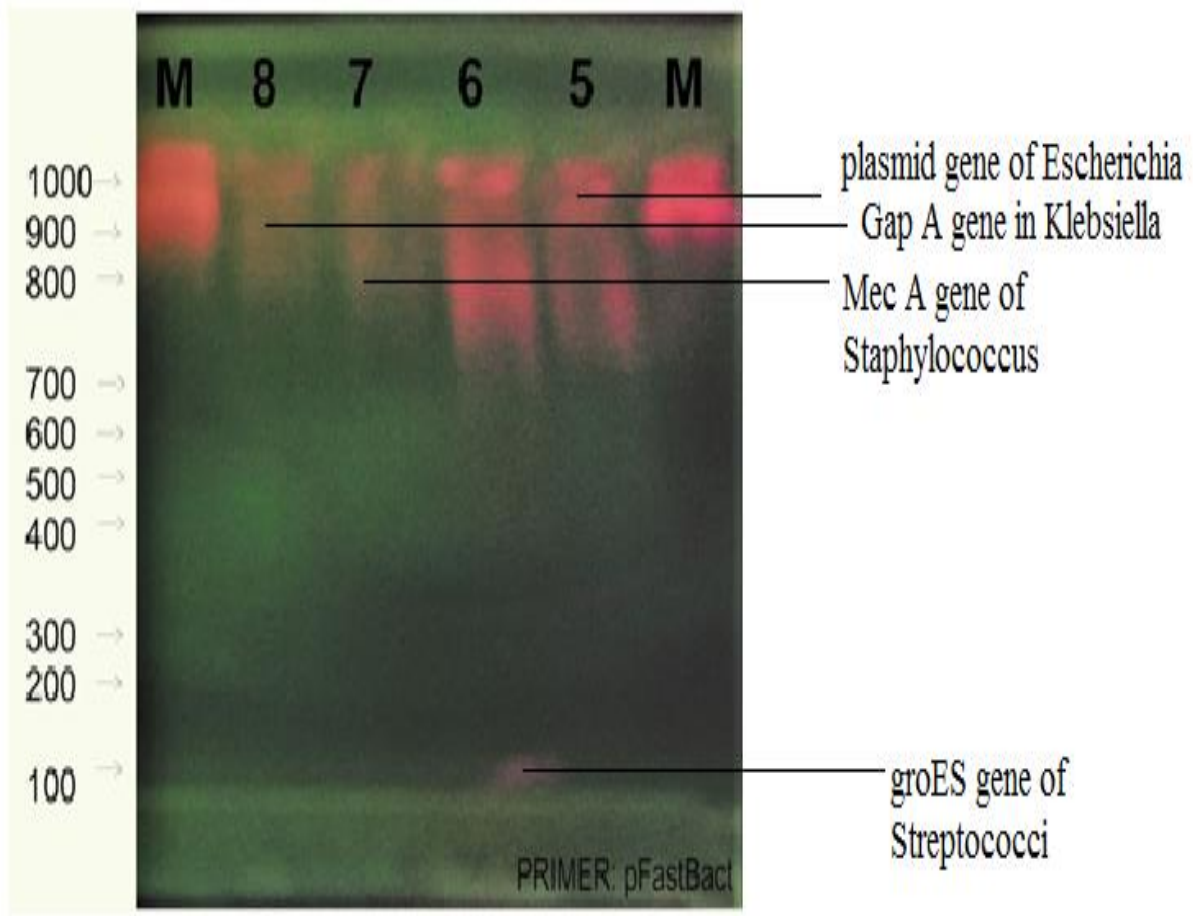

Figure 1. Gel electrophoresis of bacterial DNA of the isolates from hand pump well waters Key: M: DNA ladder.
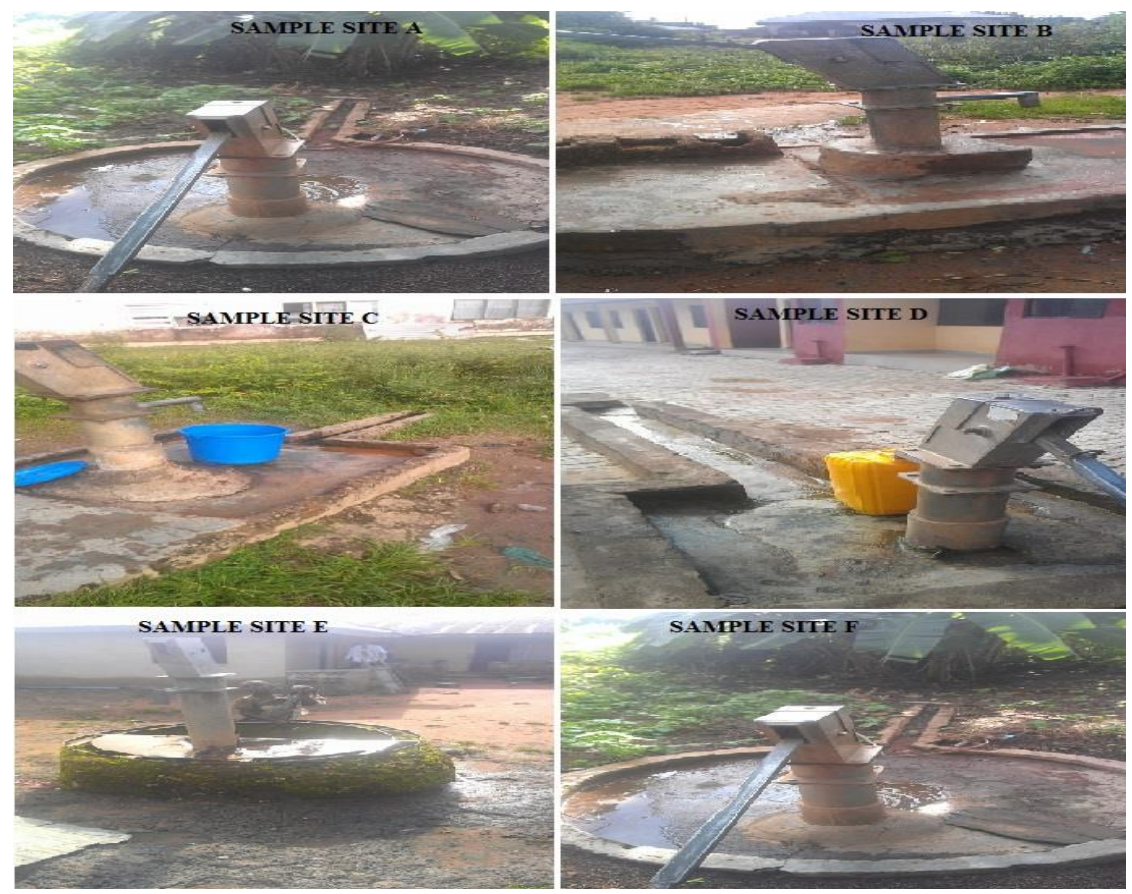

Plate 1 (A-F): Surrounding of the sampling site showing anthropogenic activities Key: Site A: Akorede; Site B: Ashomu; Site C: Government Secondary School Malete; Site D: Safari Village hostel; Site E: Isalebaale and Site F: Okete. 
Table 1: Sanitary Surveillance of the Sampling site

\begin{tabular}{|c|c|c|c|c|c|c|}
\hline $\begin{array}{l}\text { Sample } \\
\text { site }\end{array}$ & $\begin{array}{l}\text { Refuse/Solids } \\
\text { dump }\end{array}$ & Animal dung & $\begin{array}{l}\text { Floor } \\
\text { covering }\end{array}$ & $\begin{array}{l}\text { Stagnant } \\
\text { water }\end{array}$ & $\begin{array}{l}\text { Water } \\
\text { Appearance }\end{array}$ & $\begin{array}{l}\text { Proximity } \\
\text { to drainage/ } \\
\text { septic } \\
\text { system }\end{array}$ \\
\hline $\mathbf{A}$ & Close & Present & Fair & Present & Cloudy & Far \\
\hline B & Close & Absent & Poor & Present & Clean & Far \\
\hline C & Far & Present & Fair & Present & Fairly clean & Far \\
\hline D & close & Absent & Good & Absent & $\begin{array}{l}\text { Brownish and } \\
\text { offensive }\end{array}$ & Very close \\
\hline $\mathbf{E}$ & Far & Present & Poor & Absent & Clean & Very close \\
\hline $\mathbf{F}$ & Close & Present & Poor & Present & Fairly clean & Far \\
\hline
\end{tabular}

Key: Site A: Akorede; Site B: Ashomu; Site C: Government Secondary School Malete ; Site D: Safari Village hostel; Site E: Isalebaale and Site F: Okete Far (11- 14 Meters), Close (6-10Meters) and Very close (0-5 Meters). 
Table 2: Physicochemical analysis of hand pump well water samples

\begin{tabular}{|c|c|c|c|c|c|c|c|}
\hline Parameters & Site A & Site B & Site C & Site D & Site $\mathbf{E}$ & Site F & $\begin{array}{l}\text { WHO/SO } \\
\mathbf{N} \\
\text { Standard }\end{array}$ \\
\hline Colour & Cloudy & Clean & Clean & Brownish & Coloured & Coloured & Colourless \\
\hline $\begin{array}{l}\text { Temperature } \\
\left({ }^{\circ} \mathrm{C}\right)\end{array}$ & $26.5 \pm 0.24^{\mathrm{a}}$ & $29.3 \pm 0.19^{a}$ & $28.60 \pm 0.26^{\mathrm{a}}$ & $280.2 \pm 0.21^{\mathrm{a}}$ & $27.50 \pm 0.23^{\mathrm{a}}$ & $26.45 \pm 0.2^{\mathrm{a}}$ & Ambient \\
\hline pH & $7.86 \pm 0.01^{\mathrm{a}}$ & $7.83 \pm 0.00^{\mathrm{a}}$ & $7.80 \pm 0.00^{\mathrm{a}}$ & $8.20 \pm 0.012^{\mathrm{a}}$ & $7.76 \pm 0.03^{\mathrm{a}}$ & $7.6 \pm 0.00^{\mathrm{a}}$ & $6.5-8.5$ \\
\hline $\begin{array}{l}\text { Turbidity } \\
\text { (NTU) }\end{array}$ & $1.10 \pm 0.02^{\mathrm{a}}$ & $1.20 \pm 0.00^{\mathrm{a}}$ & $0.97 \pm 0.012^{\mathrm{a}}$ & $2.30 \pm 0.02^{\mathrm{b}}$ & $1.30 \pm 0.00^{\mathrm{a}}$ & $1.1 \pm 0.01^{\mathrm{a}}$ & $<5$ \\
\hline $\begin{array}{l}\text { Dissolved } \\
\text { Oxygen } \\
\text { (mg/L) }\end{array}$ & $5.50 \pm 0.13^{\mathrm{a}}$ & $5.46 \pm 0.21^{\mathrm{a}}$ & $5.43 \pm 0.01^{\mathrm{a}}$ & $6.20 \pm 0.00^{\mathrm{b}}$ & $5.57 \pm 0.05^{\mathrm{a}}$ & $5.37 \pm 0.10^{\mathrm{a}}$ & $6.5-8$ \\
\hline $\begin{array}{l}\text { Salinity } \\
(\mathrm{mg} / \mathrm{L})\end{array}$ & $0.06 \pm 0.00^{\mathrm{a}}$ & $0.017 \pm 0.06^{\mathrm{b}}$ & $0.037 \pm 0.02^{\mathrm{c}}$ & $0.01 \pm 0.00^{\mathrm{b}}$ & $0.043 \pm 0.00^{\mathrm{c}}$ & $\begin{array}{l}0.037 \pm 0.02 \\
\mathrm{c}\end{array}$ & $<1000$ \\
\hline $\begin{array}{l}\text { Conductivity } \\
(\mu \mathrm{S} / \mathrm{cm})\end{array}$ & $\begin{array}{l}87.20 \pm 0.0 \\
1^{\mathrm{a}}\end{array}$ & $97.40 \pm 0.01^{\mathrm{c}}$ & $93.41 \pm 0.00^{\mathrm{c}}$ & $83.15 \pm 0.02^{\mathrm{a}}$ & $90.01 \pm 0.00^{\mathrm{c}}$ & $64.4 \pm 0.00^{b}$ & 250 \\
\hline $\begin{array}{l}\text { Hardness } \\
(\mathrm{mg} / \mathrm{L})\end{array}$ & $3.57 \pm 0.12^{\mathrm{a}}$ & $4.2 \pm 0.00^{\mathrm{b}}$ & $3.76 \pm 0.02^{\mathrm{a}}$ & $4.13 \pm 0.01$ & $3.27 \pm 0.02^{\mathrm{a}}$ & $5.00 \pm 0.00^{\mathrm{c}}$ & $<150$ \\
\hline
\end{tabular}

Values represent means \pm standard error of means. Values with same superscript have no inferential difference while those with different superscripts have inferential difference at $95 \%$ confidence interval. $(n=6)$ along rows. 
Table 3: Bacteriological Analysis of the collected water samples

\begin{tabular}{|c|c|c|c|}
\hline Sample & $\begin{array}{l}\text { Total Heterotrophic } \\
\text { count (THC) (cfu/ml) }\end{array}$ & $\begin{array}{r}\text { Total coliform count } \\
\text { (TCC) }(\mathrm{cfu} / \mathrm{ml})\end{array}$ & $\begin{array}{r}\text { Total faecal count } \\
(\text { TFC })(\mathrm{cfu} / \mathrm{ml})\end{array}$ \\
\hline A & $1.06 \times 10^{2} \pm 3.33^{\mathrm{a}}$ & $12.0 \pm 0.58^{c}$ & $4.0 \pm 0.57^{\mathrm{a}}$ \\
\hline B & $1.56 \times 10^{2} \pm 6.67^{\mathrm{a}}$ & $5.0 \pm 0.24^{\mathrm{a}}$ & 0.00 \\
\hline $\mathbf{C}$ & $1.26 \times 10^{3} \pm 6.67^{b}$ & $9.0 \pm 0.55^{\mathrm{b}}$ & $6.0 \pm 0.54^{\mathrm{a}}$ \\
\hline D & $2.93 \times 10^{4} \pm 6.67^{c}$ & $75.0 \pm 0.63^{\mathrm{f}}$ & $65.0 \pm 0.18^{\mathrm{d}}$ \\
\hline $\mathbf{E}$ & $2.10 \times 10^{4} \pm 5.77^{\mathrm{c}}$ & $23.0 \pm 0.12^{\mathrm{e}}$ & $48.0 \pm 0.58^{c}$ \\
\hline $\mathbf{F}$ & $1.16 \times 10^{3} \pm 3.33^{b}$ & $17.0 \pm 0.26^{\mathrm{d}}$ & $11.0 \pm 0.65^{b}$ \\
\hline
\end{tabular}

Key: Site A: Akorede; Site B: Ashomu; Site C: Government Secondary School Malete; Site D: Safari Village hostel; Site E: Isalebaale and Site F: Okete Values represent means \pm standard error of means. Values with same superscript have no inferential difference while those with different superscripts have inferential difference at $95 \%$ confidence interval. $(n=6)$ along column.

\section{DISCUSSION}

Hand pumped well water and other underground water sources are major source of drinking water in Nigeria, especially among local populace, who either have no access to public pipe borne water supply or cannot afford to rely on treated bottle water for their consumption and domestic usage (Akpoveta et al., 2011). The environments surrounding the hand pumped well were largely contaminated and littered with various forms of refuse. This is large due to anthropogenic activities of the populace around pumped well. All the hand pumped wells water studied, were less than 15metres from the nearest septic tank, and the results revealed a high rate of contamination as all the hand pumped wells analyzed were contaminated with coliforms. Arwenyo et al. (2017) and Rohmah et al. (2018) who have investigated the effects of septic tank proximity to drinking water wells. They have reported similarly high values of total coliforms in different groundwater samples in their studies conducted within the country and outside the borders of Nigeria.

The temperature of the water samples in this study generally ranged from $26.45 \pm 0.2$ to $29.3 \pm 0.19^{\circ} \mathrm{C}$. No substantial variation in the temperature of the water samples. Sabo et al. (2013), recorded temperatures of between $26.38^{\circ} \mathrm{C}$ to $29.93^{\circ} \mathrm{C}$ for hand pumped well water samples in Gombe state. Temperature accounts for a whole lot of other physicochemical parameters and it is also a major determinant of the type of microorganisms found in the water. The $\mathrm{pH}$ of water is generally accepted to be neutral (7.0) (UN, 2015). Results from this study revealed variations in the $\mathrm{pH}$ of the water samples from 7.6 to 8.2, and thus falls within the values of 6.5-8.5 recommended by the Environmental Protection Agency (UN, 2006). Results 
from this study showed that turbidity across the hand pumped wells water samples were generally low. It ranged from 0.97 NTU to 2.3 NTU. The turbidity noted in this study was within the limit set by Nigerian standard for drinking water quality (UN, 2015). Similar results were obtained by Adogo et al. (2016)

No statistical difference was found among the different hand pumped well water samples studied at $\mathrm{p}<0.05$ in terms of $\mathrm{pH}$, temperature, turbidity and dissolved oxygen. The range of dissolved oxygen obtained in this study showed that very little organic pollution occurred in the water body, and was well within the standards set by NSDWQ (NSDWQ, 2007). The results obtained in this study was relatively higher than the $1.3 \mathrm{mg} / \mathrm{L}$ and $1.8 \mathrm{mg} / \mathrm{L}$ reported for private and public boreholes respectively by Ukpong and Okon (2013). Salinity was generally low in this study. It varied from $0.01 \mathrm{mg} / \mathrm{L}$ to $0.06 \mathrm{mg} / \mathrm{L}$. Similar results were obtained by Asuquo and Etim (2012) and Adogo et al. (2016). High level of salinity in borehole water samples are usually attributed to the presence of refuse dumps or septic tanks close to these underground water sources (Anne et al., 2015). Results from this research revealed that hardness of the hand pump well water samples ranged from $3.27 \mathrm{mg} / \mathrm{L}$ to $5.0 \mathrm{mg} / \mathrm{L}$ and were within recommended limits of $<150 \mathrm{mg} / \mathrm{L}$, it shows significant different at $\mathrm{p}<0.05$. These results are in agreement with the reports of Sabo et al. (2013) and Adogo et al. (2016).

Based on the morphological and biochemical characteristics, 4 major and distinct bacterial isolates Klebsiella sp., Staphylococcus aureus, Escherichia coli, and Streptococcus sp. were isolated. Both nonfecal and fecal coliform bacteria are the most contaminant organisms. The water samples with low bacteria and total coliform counts have better quality for domestic use than the ones with the highest counts of both bacteria and total coliform counts. Akinyemi et al. (2006) in their earlier studies in Lagos and Ibadan reported that water for drinking and domestic purposes from well and borehole were grossly contaminated with pathogenic organisms. Donderski and Wilki (2001) reported that fecal coliform bacteria number is an indication of the contamination size by fecal substance and also, that the total number of heterotrophic bacteria is a reflection of contamination extent by the easily decomposable organic matters.

In this study, coliforms were found in all the water samples, while fecal coliform was also found in all the samples except samples from site B (Ashomu). The presence of pathogenic microorganisms, most especially Escherichia coli and Staphylococcus aureus in hand pumped well water can be attributed to poor hygiene and sanitary practices around these sources of water.

According to WHO, no fecal coliform should be detected in any $100 \mathrm{~mL}$ of drinking water. From the result, it may be concluded that majority of the water samples appraised in this study except from sample site B (Ashomu), are not suitable for direct human consumption without prior treatment. The results of this study are similar to results of a previous study carried out by Akinyemi et al. (2006), that most well water at Sagamu are not microbiologically safe for drinking without additional treatment such as boiling or disinfection. Location of the hand-pumped well and environmental factors may be responsible for the level of contamination in some of the samples with higher number of total viable bacterial counts. Some domestic animals may also visit the site and when drinking, they lick the mouth of the hand-pumped well taps and defecate around the pump location. These activities could enhance bacterial spore to contaminate the water through the opening side.

The isolates from the water samples were further identified using molecular methods (PCR). A universal primer which targets different gene segments of various bacteria was used. While Streptococcus pneumonia was identified by the groES gene, Staphylococcus aureus was identified using the mecA gene. E. coli was identified using its plasmid and Klebsiella identified using the GapA gene. This method of identification has also been used by Hung et al. (2005) and Siri et al. (2011). 
E. coli was isolated in $83.3 \%$ of the sampled hand-pumped well water. The high density of $E$. coli in the drinking water sources may be due to untidy nature of the physical environment and proximity of some wells to toilets and refuse dump as observed particularly in sample site D (Safari village), where the handpumped well was located in student hostel, though the environment was clean and tidy, the hand-pumped well was close to a septic tank, which could account for the presence of E. coli and Streptococcus sp. in the water. The findings of this study are similar to earlier reports by Gwimbi, (2011) and Okorafor et al. (2012) in their study on physico-chemical and bacteriological characteristics of selected streams and boreholes in Akamkpa and Calabar Municipal and Maseru district Lesotho respectively where they reported high rate of coliforms contamination in all the water analyzed.

Other organisms like Klebsiella oxytoca, Staphylococcus aureus and Streptococcus pneumoniae were isolated from the water samples. Staphylococcus species are usually non-motile, catalase positive, gram-positive cocci. They are commonly present as parasites of man and they form part of bacteria flora of the skin, upper respiratory tract and intestinal tract. Staphylococcus aureus (a type species) is by far the most significant and pathogenic in the genus. It is carried in the nose of $20-40 \%$ of healthy individual (Ochei and kolhatkar, 2004). Klebsiella pneumoniae is the causative agent of chest infection and occasionally, severe broncho Pneumonia with lung abscesses (Cheesbrough, 2006).

\section{CONCLUSION AND RECOMMENDATION}

The result of this study suggests proof of hand pump well water contamination by fecal coliforms. Since majority of the well water analyzed were found to be contaminated by pathogens of fecal origin, they are consequently not fit for human consumption. Proper hand-pumped well location at a distance above 15 meters away from the septic tank is essential, public awareness on environment sanitation should be emphasis. Also hand-pumped well samples that do not meet the standard should be treated before consumption.

\section{ACKNOWLEDGEMENT}

The authors acknowledge the management of Kwara State University, Malate, Nigeria for making Laboratory facilities available for the study.

\section{REFERENCES}

Adeyemi, O., Oloyede, O.B., Oladiji, A.T. (2007). Physicochemical and Microbial characteristics of Leachate contaminated ground water. Asian Journal Biochemistry, 2 (5), 343-348.

Adogo, L. Y., Ajiji, M. A., Anyanwu, N. C. J., Ajide, B. (2016). Bacteriological and Physicochemical Analysis of Borehole Water in AutaBalefi Community, Nasarawa State, Nigeria. British Microbiology Research Journal, 11(4), 1-7.

Akinyemi, O.K., Oyefolu, A.O.B., Salu, O.B., Adewale, O.A., Fasure, A. K. (2006). Bacterial associated with Tap and Well water in Lagos,
Nigeria. East and Central African Journal of Surgery, 2 (1), 110-117.

Akpoveta, O.V., Okoh, B.E., Osakwe, S.A. (2011): Quality Assessment of Borehole Water Used in the Vicinities of Benin, Edo State and Agbor, Delta State of Nigeria.Current Research in Chemistry, 3(1), 62-67.

Arwenyo, B., Wasswa, J., Nyeko, M., Kasozi, G. N. (2017). The impact of septic systems density and nearness to spring water points, on water quality. African Journal of Environmental Sciences and Technology, 11 (1), 11-18. 
American Public Health Association (APHA) (1981). Standard Methods for the Examination of Water and Wastewater (15 ${ }^{\text {th }}$ Edition). APHA; Washington, DC, USA. Pp. 85 - 99 pp. 773 - 779, $786-828$.

Aneja, K .R. (2003). Experiment in Microbiology, Plant Pathology and Biotechnology. New Age International, New Delhi. 606.

Anne, P., Omeire, G.C., Okafor, D.C., Eluchie, C., Odimegwu, N.E., Nze, S.N., Anagwu, F.I., Okeke, K.C. (2015). Assessment of the Quality of Borehole Water Sample in Federal Housing Estate and Sites and Services Areas of Owerri, Imo State, Nigeria. Food Science and Quality Management, 42, 5-12

Asuquo, J.E., Etim, E.E (2012). Water quality Index for assessement of borehole water quality in Uyo metropolis Akwa ibom state, Nigeria.

International journal of Modern Chemistry, 1 (3), 102-108.

Cheesbrough M., (2006). "District laboratory Practice in Tropical Countries." Part 2. Cambridge University Press. 143-157.

Donderski, W., Wilk, W. (2001): Bacteriological Studies of Water and Bottom Sediments of the Vistula Review between Wyszogrod and Torun. Polish Journal of Environmental Studies, 2 (1), 33 40.

Fawole, M.O., Oso, B.A. (2004). Laboratory Manuel of Microbiology, published by Spectrum Books Limited, Sunshine House, Ring Road, Ibadan, Nigeria, 1,48.

Gwimbi, P. (2011). The microbial quality of drinking water in Manonyane community:Maseru district (Lesotho). Africa Health Science, 11(3), 474480 .

HAGUE (2019). Quality Water: Drinking contaminated water sources/ and or dirty water can cause numerous health concerns. Website, https:www.haguewaterofmd.com. Retrieved: $7 / 2 / 2020$
Ivey, J.L., De Loe, R., Kreutzwiser, R., Ferreyra. C. (2006). An institutional perspective on local capacity for source water protection, Geoforum, 37, 944-957.

Kolawole, O.M., Alamu, F.B., Olayemi, A.B., Adetitun, D.O. (2013). Bacteriological analysis and effects of water consumption on the hematological parameters in rats. Int. J. Plant, Animal and Environ. Sci., 3(2), 125 - 131

Miller, C.S.; Handley, K.M.; Wrighton, K.C.; Frischkorn, K.R.; Thomas, B.C.; Banfield, J.F., (2013). Short-read assembly of full-length $16 \mathrm{~S}$ amplicons reveals bacterial diversity in subsurface sediments. PloS one 2013, 8(2), e56018.

NSDWQ (2007). Nigeria Standard for Drinking Water Quality, Nigeria Industrial Standard, Approve by Standard Organization of Nigeria Governing Council. ICS 13. 060. 20, 15-19.

Ochie, J.O., Kolhatkar, A.A. (2004): Medical Laboratory Science: Theory and Practice. Tata Mc Graw - Hill Publishing Company Lt, New Delhi, $530-831$.

Okorafor, K.A., Agbo, B.E., Johnson, A.M., Chiorlu. M. (2012). Physic-chemical and bacteriological characteristics of selected streams and boreholes in Akamkpa and calabar municipality, Nigeria. Arch. Appl. Sci. Res., 4(5), 2115-2121.

Rohmah, Y., Rinanti, A., Hendrawan, D. I. (2018). The determination of groundwater quality based on the presence of Escherichia coli on populated area (a case study: Pasar Minggu, South Jakarta). Earth and Environmental Sciences 106. The $4^{\text {th }}$ International Seminar on Sustainable Urban Development IOP Publishing IOP Conf. Series.

Sabo, A. and Eyaife, O.C. (2014). Physicochemical and BacteriologicalQuality of Ground Water at AbubakarTatari Ali Polytechnic Bauchi, Nigeria. European Scientific Journal June, 10, 18

Siri, G.P., Sithebe, N.P., Ateba, C.N. (2011). Identification of Klebsiella species isolated from Modimola dam (Mafikeng) North West Province - 
South Africa. African Journal of Microbiology Research, 5(23), 3958-3963

Thomas B. (2017). City population: Moro Local Government of Nigeria).

https:www.citypopulation.de/php/Nigeriaadmin.ph p?adm2id=NGA024012.Retrieved: 7/2/2020.

Ukpong, E. C., Okon, B. B (2013). Comparative Analysis of Public and Private Borehole Water Supply Sources in Uruan Local Government Area of Akwa Ibom State International Journal of Applied Science and Technology, 3 (1), 76-91.

UNEPA (2006): Water Quality for Ecosystem and Human Health. United Nations. Environmental Programme. Global Environment Monitoring System / Water programme National Water Research Institution; Ontario, Canade. (http: // www. Gers water.org), $32-53$.

United Nations (UN), 2015. "International Decade for Action (water for life) 2005 - 2015." Retrieved $31 / 7 / 15$ from: http://www.un.org/waterforlifedecade/background.s html

WHO. (2016). Health through safe drinking water and basic sanitation http://www.who.int/water_sanitation_health/mdg1/ en/Accessed 15/01/2019 